\title{
IDENTIFICATION OF KEY TARGET MARKETS FOR INTERMODAL FREIGHT TRANSPORT SOLUTIONS IN SOUTH AFRICA
}

\author{
JOUBERT VAN EEDEN* \\ JAN HAVENGA \\ *jveeden@sun.ac.za
}

Centre for Supply Chain Management, Department of Logistics

Stellenbosch University

South Africa

\begin{abstract}
The Accelerated and Shared Growth Initiative for South Africa (AsgiSA) identified South Africa's freight logistics challenges as among the key binding constraints on the country's growth aspirations. The research presented here points to the structural imbalance between road and rail freight transport as one of the key contributors to this state of affairs. Most long-distance corridor transport has been captured by road. However, longdistance transport is a market segment that is very suitable for intermodal transportation: rail is utilised for the high-density, long-distance component and road for the feeder and distribution services at the corridor end points. A market segmentation approach is developed to identify the corridors and industries that are natural candidates for such solutions, thereby paving the way for role-players and stakeholders to initiate a dialogue on the development of appropriate solutions.
\end{abstract}

\section{INTRODUCTION}

The high cost, inefficiency and strained capacity of the national logistics system are among the six binding constraints identified by the Accelerated and Shared Growth Initiative for South Africa (AsgiSA) (Republic of South Africa, 2004).

Totalling R339 billion, or 14.7\% of GDP in 2008 (Havenga, Van Eeden \& Simpson [SOL], 2009: 15), South Africa's logistics cost as a percentage of GDP is high compared with, for example, that of the United States (10.1\% in 2007) (Wilson, 2008: 1) and of Japan (10\%) (United Nations, 2002: 22). In South Africa, transport costs constitute 50\% of the country's total logistics costs (Havenga et al. [SOL], 2009) - a considerably higher proportion than the world average of 39\% (Rodrigue, Comtois \& Slack, 2009). Freight transport users have been willing to pay this premium for the speed and reliability offered by road transport. However, from a macroeconomic perspective, road freight transport results in the inefficient allocation of production factors, compounded by externalities. Externalities for South Africa are estimated at R34 billion (compared to the total freight 
bill of R171 billion). Externalities include emissions, congestion, accidents, policing and noise (Havenga et al. [SOL], 2009: 22).

This is evidenced by the fact that R118 billion of the R171 billion (more than two-thirds) of total freight transport cost is attributable to road freight transport on corridors. In tonkilometre terms (ton-km), rail corridor traffic declined by almost 20\% in the past 15 years, whereas, in the same period, road corridor traffic more than doubled (Havenga et al. [SOL], 2009: 21). Current total South African freight volume is 297 billion ton-km, of which 105 billion ton-km is on rail, and 192 billion ton-km is on road (Havenga, Van Eeden \& Simpson [FDM], 2009). This tendency for long-distance freight transport growth to be captured predominantly by road transport has a profound impact on both the South African road infrastructure (through overutilisation) and rail infrastructure (through underutilisation); the trend also ultimately influences the competitiveness of the users of the infrastructure.

Global research highlights the significant differences between road and rail transport costs. Ballou (2004: 168) indicates that the potential cost-saving for rail compared with road transportation in the United States is considerable, with the total cost for road as much as 12 times more than that for rail. In 2006, a US government study (Kwan \& Knutsen, 2006: 22) established that one US gallon of fuel is needed to carry one ton of goods for $96 \mathrm{~km}$ by truck, $325 \mathrm{~km}$ by rail and $828 \mathrm{~km}$ by barge.

South African rail freight transport's current core competence is the transport of highvolume export minerals, namely coal, iron ore and manganese, described in this paper as the primary transport market. Rail needs to identify freight transport segments that suit the long-haul, high-density nature of its core competence - essentially, freight that behaves more like the primary traffic, in the handling of which it is so efficient. This implies market segments that can be described as having few origins and few destinations, and which are separated by substantial distances. These market segments are especially suitable for rail transport on the long-haul section, and thus indicate intermodal solutions.

One of the key methods of addressing high logistics costs would, therefore, appear to be to shift suitable long-distance freight transport to rail in order to take advantage of rail's core competence. A principal tenet of the South African government's road freight strategy is to facilitate an optimum split of cargo between road and rail (Ndebele, 2009). Recent experience has indicated that industry will support this, provided that the rail service is efficient and reliable. Increased efficiencies at the Durban port and City Deep logistics hub, which forms part of the revitalisation of the Gauteng-Durban corridor, had the effect of blue-chip companies such as Woolworths, LG and BMW electing to re-entrust container transport to rail (Dlamini, 2009). 
These minor breakthroughs illustrate the benefits of further developing intermodal solutions through collaborative planning between all modes of transport. Nevertheless, the significant investments planned in road and rail capacities still seem to be made in isolation. The figure of R106 billion has been allocated to national and provincial roads over the next three years (National Treasury, 2009a, 2009b); and Transnet is planning to invest R44 billion in freight rail infrastructure and rolling stock (Transnet, 2009).

The purpose of this paper is to present the results of a market segmentation approach that enables the identification of the key target markets for such intermodal solutions, which could direct collaborative infrastructure investment discussions.

\section{RESEARCH APPROACH}

\section{Developing a freight flow model}

Prior to the development of the work presented in this paper, the key challenge facing South African transport infrastructure planners was the unavailability of comprehensive freight flow data.

In 2006, the Centre for Supply Chain Management (CSCM) at the Department of Logistics, Stellenbosch University, developed a freight demand model (FDM) for Transnet. The purpose of the model is to gain an understanding of the future demand for freight transport in South Africa to assist in capital-investment decisions. This model is refined and updated annually.

The FDM estimates all freight flows in South Africa (summarised into 64 commodity groups) between 356 magisterial districts in tons and ton-kilometres, with 30-year forecasts and for three growth scenarios. The flow estimation is based on gravity modelling of the supply and demand per magisterial district per commodity group. Actual historic rail freight data is subtracted from the modelled flows, resulting in a comprehensive view of road freight transport. The resulting model has more than 1 million records of freight flow data between defined origin and destination pairs and for all commodity groupings. (Refer to Havenga, 2007 for a detailed description of the model.)

The model provides total flows (including domestic maritime and air transport, which make up less than $1 \%$ of domestic freight transport); however, for the purposes of this paper the focus is only on the surface freight transport market, i.e. road and rail.

\section{Defining long-haul or corridor traffic}

Surface freight transport can be divided into four distinct typologies. The salient characteristics of each typology are compared in Table I. 
Table I: Definition of transport typologies (Havenga, 2007: 146)

\begin{tabular}{|l|l|l|l|l|}
\hline & Primary & Corridor & Rural & Metropolitan \\
\hline Traffic type & $\begin{array}{l}\text { Bulk, low-value (rail } \\
\text { only, mainly export } \\
\text { coal and iron ore) }\end{array}$ & $\begin{array}{l}\text { Higher value, mostly } \\
\text { manufacturing and } \\
\text { some agriculture }\end{array}$ & Mostly agriculture & Mostly final delivery \\
\hline Distance & Long & Long and short & Medium and short & Short \\
\hline $\begin{array}{l}\text { Origin-destination } \\
\text { (OD) pairs }\end{array}$ & $\begin{array}{l}\text { Few, usually one- } \\
\text { directional }\end{array}$ & $\begin{array}{l}\text { Few long-distance } \\
\text { ODs; many ODs at } \\
\text { end points }\end{array}$ & Many & Many \\
\hline Major challenge & $\begin{array}{l}\text { Global } \\
\text { competitiveness }\end{array}$ & $\begin{array}{l}\text { Spatial organisation, } \\
\text { efficiency }\end{array}$ & Development & $\begin{array}{l}\text { Congestion } \\
\text { alleviation }\end{array}$ \\
\hline Logistics approach & $\begin{array}{l}\text { Ring-fenced, bulk } \\
\text { rail systems }\end{array}$ & Intermodal solutions & $\begin{array}{l}\text { Effective road } \\
\text { feeder system }\end{array}$ & $\begin{array}{l}\text { World-class } \\
\text { commuter systems } \\
\text { and effective } \\
\text { freight delivery }\end{array}$ \\
\hline
\end{tabular}

Corridors provide the link between origin-destination (OD) pairs in different metropolitan areas. Corridor traffic can be transformed to fewer OD pairs if the collection and distribution can be performed efficiently from a central hub at both ends of the long-distance corridor. The only way to do this effectively is by implementing intermodal solutions, which transform the corridor to a combination of primary traffic (end-to-end) and metropolitan traffic (shortdistance distribution).

The FDM result was aggregated to define the primary, rural, metropolitan and corridor flow typologies for each commodity group. Given the short-distance nature of intra-metropolitan traffic, this typology is not deemed to be an intermodal-friendly market share and will not be discussed further in this paper.

\section{Key transport economics principles}

Two of the key rail economics principles are freight uniformity and long-distance line density. These concepts are briefly discussed in the following sections.

\section{Defining freight uniformity}

Products need to be uniform (such as dry bulk - i.e. coal, iron ore, maize, wheat) or require some form of standardisation, such as being palletised or containerised. Because of the uniformity of the product, mechanical handling can allow very large quantities to be handled quickly and efficiently. The economic advantages of standardisation are both direct (i.e. lower distribution costs) and indirect (e.g. reductions in packaging costs and damage rates). The direct advantages accrue not only to the consignor, but also to the transport companies (through improved consolidation and capacity management) and often to the consignee as well. The consignor saves on handling and storage costs in its own warehouse, as well as on shipment charges. 


\section{Defining line density}

Globally, flow density is measured by comparing the combination of distance and tons to the investment in route infrastructure, namely in ton-km per route-kilometre (ton- $\mathrm{km} \div$ route-km). In 1977, Robert G. Harris wrote a seminal paper (Harris, 1977), stating (present author's italics):

The extent of economies of traffic density in the rail freight industry is a matter of critical importance with respect to public investment in and the financial viability of the United States rail system. The evidence strongly supports the hypothesis that significant economies of density exist, and that many of the light-density lines, which comprise 40 percent of the rail system, should be eliminated.

This comment focuses on the light-density lines to be eliminated; however, it also emphasises that rail should be utilising and increasing volumes on high-density lines, and thus increasing density to the point where efficient economies of scale are achieved. The current total rail density for South Africa for general freight (export lines excluded) is 1.7 million ton-km/route$\mathrm{km}$ (meaning that 1.7 million tons of general freight on average passes over every kilometre of rail route used by general freight). A curve for South African conditions was developed using the cost for five different rail services (coal and iron ore, containers, manganese, General Freight Business (GFB) block loads and GFB truck loads) obtained from the railway. The route-km required and costs for each service were plotted on a curve developed by Harris. Based on Harris's finding it was determined that a shift of rail-friendly corridor freight (rail-friendly as determined by the railway) will result in a $36 \%$ reduction in rail costs that will contribute to South Africa's competitiveness in global markets (Havenga, 2010).

\section{The market segmentation approach}

The previous comment depends on the following assumptions:

- For rail, suitable freight is dependent on longer-haul, dense routes with limited handling.

- For customers, an efficient and reliable service implies, inter alia, a door-to-door service.

- In combination, this implies intermodal solutions.

The process of market segmentation followed was, first, to segment the market into typologies, i.e. traffic that behaves in similar patterns. Secondly, these typologies were analysed to find the most suitable freight segments from a perspective of transport density. Thirdly, the highest-density segments were analysed to find the types of freight to be moved in these segments, i.e. specific commodity groups that make use of these high-density typologies. Through this process, the so-called 'low-hanging fruit' can be established in order to enable the appropriate role-players to start the initiative of establishing intermodal transport solutions for South Africa. 


\section{DISCUSSION}

\section{Market segmentation by typology}

For context, the total South African freight transport market of 297 billion ton-km in 2008 is depicted by typology in Figure 1. Rail's current market share within each typology is also shown, and, as mentioned previously, metropolitan freight (5.3 bn ton- $\mathrm{km} ; 1.8 \%$ ) is excluded.

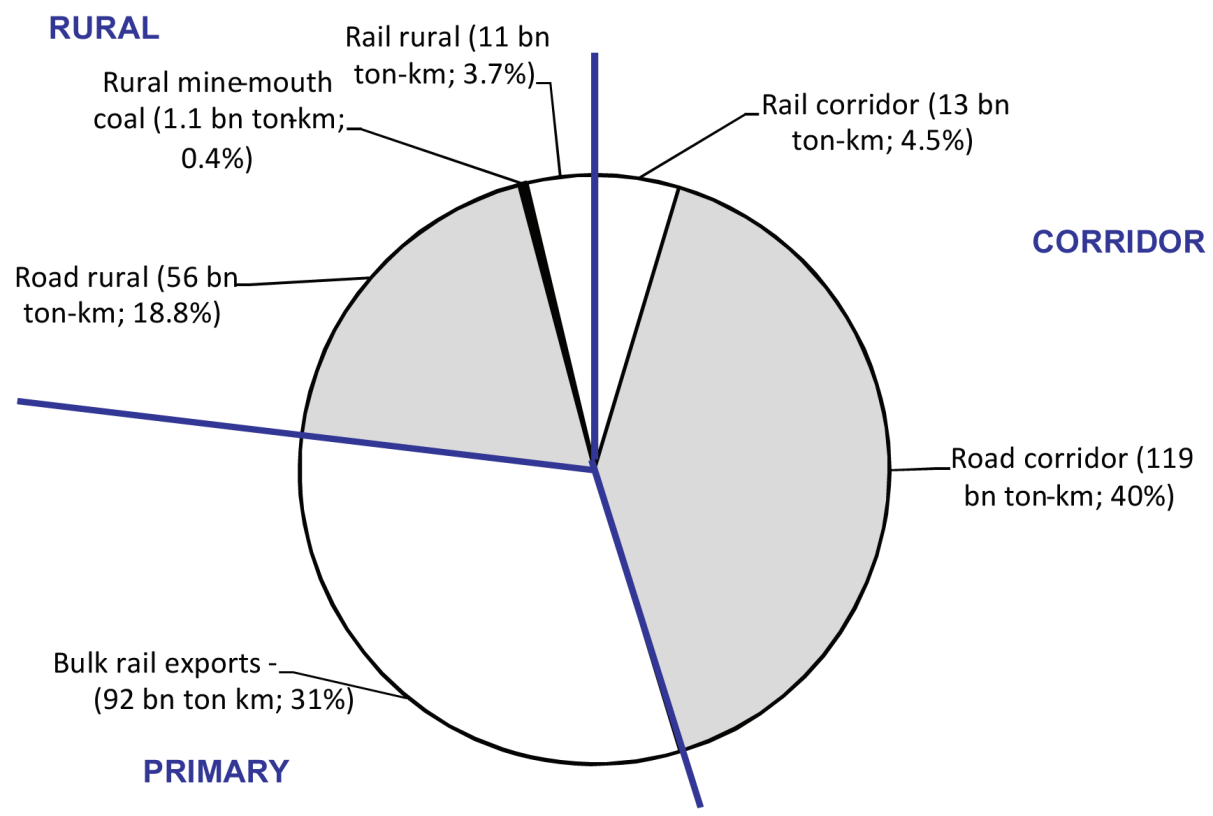

Figure 1: Freight transport by typology: billion ton-km and percentage share (data source: FDM, 2009)

The current typology distribution can be described as follows:

- Primary: Rail has $100 \%$ market share of the ring-fenced bulk export traffic. This market is non-contestable for road carriers.

- Rural: Rail has captured 11 billion ton-km of the rural flows, contributing $4 \%$ of the total transport demand. The mine-mouth rural coal flow (1.1 billion ton- $\mathrm{km}$ ), which runs from coal mines directly to power stations via conveyor belts, should be viewed as a market that cannot be penetrated by rail. Though limited, some of the remaining longerdistance rural traffic may be seen as part of a contestable market. However, it may be difficult to achieve financial viability owing to the low density caused by many-to-many OD combinations.

- Corridor: Rail has captured 13 billion ton-km of the corridor traffic, contributing $5 \%$ to the total transport demand. In 2008, the remaining 119 billion ton-km were hauled over long distances by road carriers, and should be seen as a contestable market share for rail. This holds especially true for the high-density corridors.

\section{Market segmentation by density}

As described previously, transport density is globally measured in ton-km/route-km. This measure is combined with the average travel distance (ATD) to identify the most attractive 
freight demand typologies. The corridor market is now analysed further to determine which specific corridors provide the most attractive prospects for intermodal solutions.

Figure 2 shows the market segmentation by corridor, with the rail market share indicated for the two most attractive corridors: Durban-Gauteng and Cape Town-Gauteng. Combined, the Durban-Gauteng and Cape Town-Gauteng corridors contribute more than 50\% of the ton-km for this transport typology, and are comparable to the iron ore export line in terms of line density, which was deemed as best of its class in the world in a recent study (Department of Public Enterprises, 2010). Both these corridors appear to offer the most attractive rail prospects, with ton-km/route-km values well over 20, despite rail currently having a 19.2\% and $7.2 \%$ market share, respectively, of the two corridors. The higher relative position of the Cape Town-Gauteng corridor (compared to the Durban-Gauteng corridor) highlights the intrinsic principles of rail economics and the advantages of shifting freight from road to rail. Even though less freight (in tons) is moved on the corridor, the ATD is higher and more ton-km is generated. As rail freight costs are less dependent on distance than road freight, longer transport distances favour rail transport.

The breakeven distance where the impact of higher terminal costs for rail is offset by the cost reduction has been calculated for South Africa to be $300 \mathrm{~km}$, i.e. transporting freight under current circumstances in South Africa over a longer distance than $300 \mathrm{~km}$ should be cheaper by rail long haul and road distribution than by road only (Havenga, Van Eeden \& Simpson [FDM], 2009). Similar calculations have been done in studies for scenarios in Europe and were found to be $400 \mathrm{~km}$ (Williams and Hoel, 1998) and 500 km (Van Klink \& Van den Berg, 1998: 3). Both the corridors under discussion have an ATD of well over $500 \mathrm{~km}$.

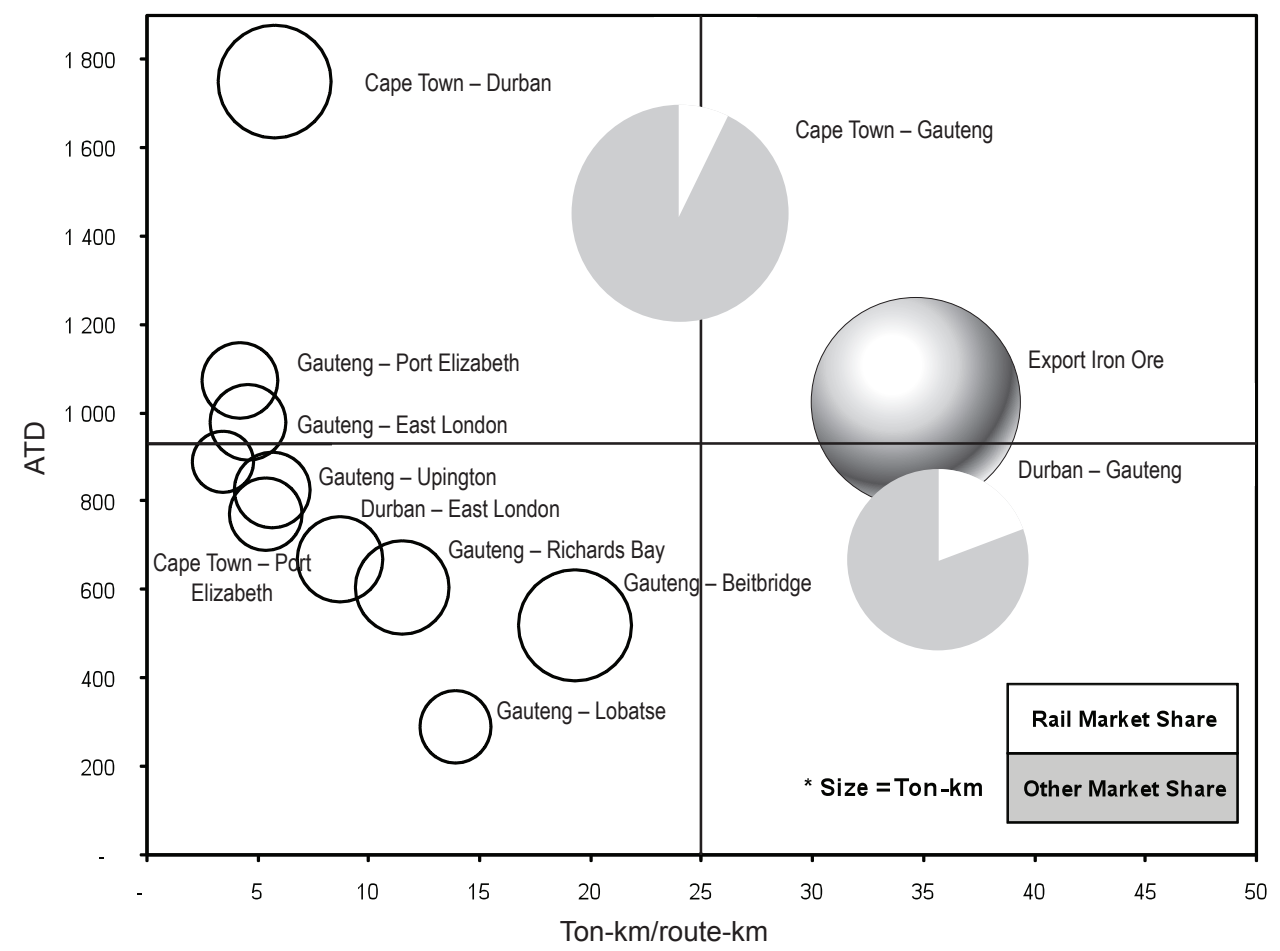

Figure 2: Market segmentation - potential corridor density (data source: FDM, 2009) 
When looking at the 30-year forecast (see Figure 3), the most significant future volumes are also expected on the Cape Town-Gauteng and Durban-Gauteng transport corridors. The Durban-Gauteng and Cape Town-Gauteng corridors will remain, respectively, about three times and twice as large as the third-largest corridor, and continue to constitute almost 50\% of the total corridor ton-km. These corridors, therefore, remain the target segments over the forecast horizon.

Further analyses in this paper will, therefore, focus on identifying the major commodities transported on the Durban-Gauteng and Cape Town-Gauteng corridors to enable further prioritisation.

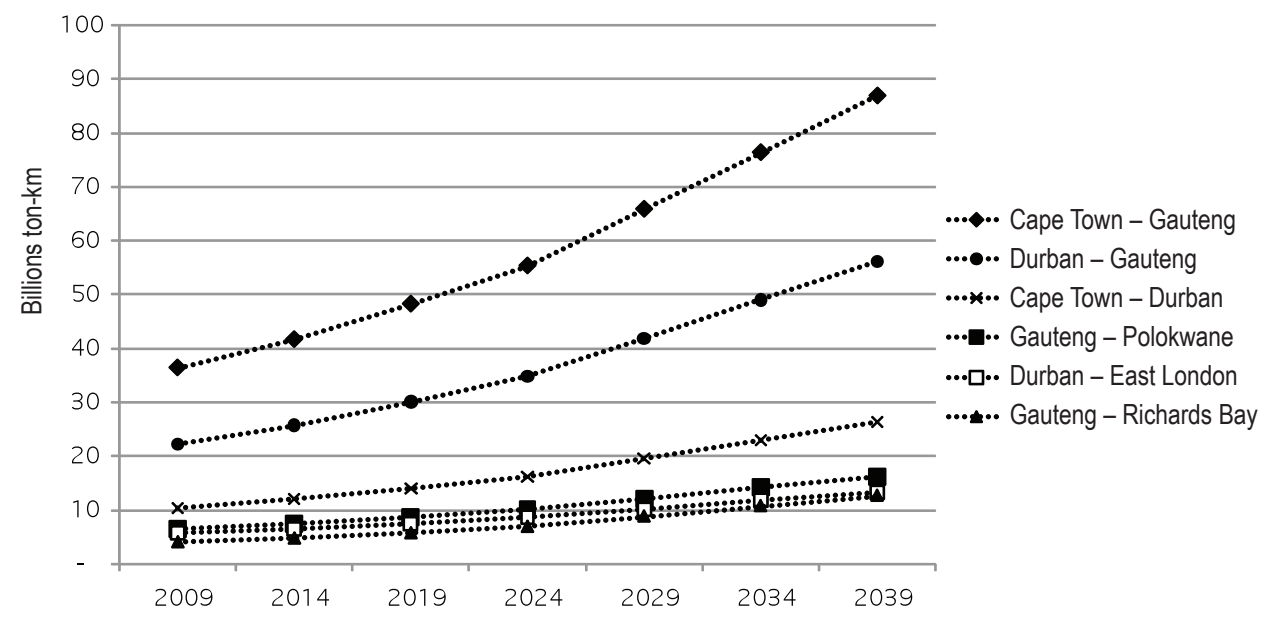

Figure 3: Corridor growth in the top six corridors (bidirectional, road-rail traffic) (data source: FDM, 2009)

\section{Market segmentation by commodity}

A Pareto analysis was undertaken to determine the largest commodity groups on each of the two identified corridors respectively using the 2039 forecasted ton-km to ensure that infrastructure investment will be able to serve the future growth markets. The result of this analysis is shown in Table II.

Table II: Pareto analysis (based on 2039 ton-km) of commodities for the two target corridors (billion ton-km) (data source: FDM, 2009)

Durban-Gautenq corridor
\begin{tabular}{|l|r|r|c|c|}
\hline Commodity & $\mathbf{2 0 0 9}$ & $\mathbf{2 0 3 9}$ & Rail MS & \%of corridor \\
\hline Fuel \& petroleum products & 4.1 & 10.4 & $6 \%$ & $19 \%$ \\
\hline Processed foods & 4.0 & 7.5 & $2 \%$ & $13 \%$ \\
\hline Iron \& steel & 1.0 & 3.6 & $23 \%$ & $6 \%$ \\
\hline Other chemicals & 1.2 & 3.4 & $2 \%$ & $6 \%$ \\
\hline Beverages & 1.4 & 2.5 & $1 \%$ & $4 \%$ \\
\hline Wood \& wood products & 0.8 & 2.3 & $7 \%$ & $4 \%$ \\
\hline Industrial chemicals & 0.7 & 2.3 & $27 \%$ & $4 \%$ \\
\hline Paper \& paper products & 0.8 & 2.0 & $3 \%$ & $4 \%$ \\
\hline Coal & 0.9 & 1.6 & $99 \%$ & $3 \%$ \\
\hline Non-metallic mineral products & 0.5 & 1.5 & $2 \%$ & $3 \%$ \\
\hline Machinery and equipment & 0.3 & 1.2 & $0 \%$ & $2 \%$ \\
\hline Wheat & 0.4 & 1.1 & $37 \%$ & $2 \%$ \\
\hline Other commodities & 6.0 & 16.7 & $12 \%$ & $30 \%$ \\
\hline
\end{tabular}

Cape Town-Gauteng corridor

\begin{tabular}{|c|c|c|c|c|}
\hline Commodity & 2009 & 2039 & Rail MS & $\%$ of corridor \\
\hline Processed foods & 8.1 & 15.1 & $0 \%$ & $17 \%$ \\
\hline Other mining & 3.2 & 8.5 & $0 \%$ & $10 \%$ \\
\hline Coal & 3.5 & 8.1 & $11 \%$ & $9 \%$ \\
\hline Beverages & 3.4 & 6.4 & $6 \%$ & $7 \%$ \\
\hline Other chemicals & 2.2 & 6.0 & $2 \%$ & $7 \%$ \\
\hline Non-metallic mineral products & 1.6 & 4.4 & $3 \%$ & $5 \%$ \\
\hline Fuel \& petroleum products & 1.3 & 3.9 & $1 \%$ & $4 \%$ \\
\hline Wood \& wood products & 1.3 & 3.8 & $0 \%$ & $4 \%$ \\
\hline Fertilizer & 1.5 & 3.3 & $0 \%$ & $4 \%$ \\
\hline Iron \& steel & 0.9 & 3.1 & $3 \%$ & $4 \%$ \\
\hline Paper \& paper products & 0.7 & 1.8 & $2 \%$ & $2 \%$ \\
\hline Other agriculture & 0.8 & 1.8 & $0 \%$ & $2 \%$ \\
\hline Other commodities & 7.8 & 20.9 & $5 \%$ & $24 \%$ \\
\hline
\end{tabular}


A comparison of the top commodities for the two key corridors with the top commodities for all corridors shows a considerable overlap (see Table III). This will facilitate the application of findings from the implementation of successful intermodal solutions on the two target corridors on the other corridors.

Table III: Pareto analysis (based on 2039 ton-km) of commodities for corridors (excluding Durban-Gauteng and Cape Town-Gauteng) (data source: FDM, 2009)

\begin{tabular}{|l|c|c|c|c|}
\hline Commodity & $\mathbf{2 0 0 9}$ & $\mathbf{2 0 3 9}$ & Rail MS * & \% of corridor \\
\hline Processed foods & 12.3 & 22.9 & $1 \%$ & $13 \%$ \\
\hline Other mining & 6.5 & 17.3 & $0 \%$ & $10 \%$ \\
\hline $\begin{array}{l}\text { Fuel \& petroleum } \\
\text { products }\end{array}$ & 4.1 & 11.2 & $12 \%$ & $6 \%$ \\
\hline Limestone & 4.0 & 10.7 & $8 \%$ & $6 \%$ \\
\hline $\begin{array}{l}\text { Wood a\& wood } \\
\text { products }\end{array}$ & 3.5 & 10.4 & $23 \%$ & $6 \%$ \\
\hline Other chemicals & 3.4 & 8.9 & $1 \%$ & $5 \%$ \\
\hline Coal & 3.3 & 8.7 & $89 \%$ & $5 \%$ \\
\hline Beverages & 4.5 & 8.3 & $27 \%$ & $5 \%$ \\
\hline $\begin{array}{l}\text { Non-metallic } \\
\text { mineral products }\end{array}$ & 2.5 & 7.0 & $34 \%$ & $4 \%$ \\
\hline Cement & 2.6 & 6.7 & $0 \%$ & $4 \%$ \\
\hline $\begin{array}{l}\text { Other non-ferrous } \\
\text { metal mining }\end{array}$ & 1.6 & 6.7 & $19 \%$ & $3 \%$ \\
\hline Industrial chemicals & 1.5 & 4.9 & $16 \%$ & $30 \%$ \\
\hline Other commodities & 20.2 & 53.4 & $2 \%$ & \\
\hline
\end{tabular}

* MS = market share

A combination of the two key corridors' and the other corridors' most important commodities indicates that the most attractive markets for intermodal solutions are those of:

- processed foods

- beverages

- chemicals (other)

- paper and paper products

- wood and wood products.

These five commodities are all easily palletised and/or containerised, and are, therefore, candidates for intermodal solutions. A considerable portion of the fuel and petroleum products on the Durban-Gauteng corridor is transported by the existing pipeline, and consequently does not present an opportunity for intermodal solutions in its entirety. Industrial chemicals and iron and steel also seem to have some opportunities for intermodal transportation, owing to their moderate volume and current low rail market share. 
Table IV indicates the additional ton kilometres that could be achieved on the DurbanGauteng and Cape Town-Gauteng corridors if a 50\% shift from the road transport mode to intermodal solutions in each of the five mentioned commodities could be achieved. Currently, rail has about 0.19 billion ton-km of the Durban-Gauteng corridor and 0.26 billion ton-km of the Cape Town-Gauteng corridor for the five commodities concerned. If rail were to increase its market share to $50 \%$ for these five commodities alone, it could increase its current total volume along the Cape Town-Gauteng corridor by more than six times, while more than doubling its market share of the Durban-Gauteng corridor. Calculations indicate that adding these ton-kilometres to the current rail volumes will increase rail's general freight density from 1.7 to 2.3 ton-km/route-km.

Table IV: Gains for rail transportation from key commodities (billion ton-km) (data source: FDM, 2009)

\begin{tabular}{|l|c|c|c|c|}
\hline Corridor & \multicolumn{2}{|c|}{ DBN-GT } & \multicolumn{2}{c|}{ CPT-GT } \\
\hline Commodity & $\mathbf{2 0 0 9}$ & $\mathbf{2 0 3 9}$ & $\mathbf{2 0 0 9}$ & $\mathbf{2 0 3 9}$ \\
\hline Processed foods & 1.9 & 3.7 & 4.0 & 7.6 \\
\hline Beverages & 0.7 & 1.2 & 1.5 & 3.0 \\
\hline Other chemicals & 0.6 & 1.7 & 1.1 & 3.0 \\
\hline $\begin{array}{l}\text { Wood \& wood } \\
\text { products }\end{array}$ & 0.3 & 1.1 & 0.6 & 1.9 \\
\hline $\begin{array}{l}\text { Paper \& paper } \\
\text { products }\end{array}$ & 0.4 & 1.0 & 0.3 & 0.9 \\
\hline Total & $\mathbf{3 . 9}$ & $\mathbf{8 . 7}$ & $\mathbf{7 . 6}$ & 16.3 \\
\hline
\end{tabular}

This understanding of the key future commodities on both target corridors will enable freight transport service providers to approach the key industry players in these commodity segments in order to design truly collaborative intermodal solutions.

\section{CONCLUSION}

One of the key components in addressing South Africa's high logistics costs and strained logistics capacity is to engineer solutions that will lead to a more sustainable balance between road and rail freight transport.

The market segmentation analysis indicated that South Africa has two high-density, longdistance corridors (Durban-Gauteng and Cape Town-Gauteng), which are ideal candidates for intermodal solutions.

Five commodity groups with significant volumes on these two corridors were identified. The markets that are attractive for intermodal solutions are: 
- processed foods

- beverages

- other chemicals

- wood and wood products

- paper and paper products.

The market segmentation enabled by the results of the FDM reveals, for the first time, which industries are ripe for the development of intermodal solutions.

This paper did not aim to quantify the desirable market share that should be achieved by an intermodal solution, but to identify its potential and highlight the benefit for South Africa and freight owners. Nor was the aim of this paper to develop a business case, and much more work is required to quantify the investment required to achieve this objective.

The next step would be for Transnet, as the only player in South African rail freight transport, and one or more of the leading role-players in road transport in South Africa to come together and commit to a collaborative development of intermodal solutions. Subsequently, the producers of the target commodities should be approached to jointly design this service.

The research highlights a clear opportunity; the onus now rests on logistics service providers and freight owners to make this a reality. 


\section{REFERENCES}

Ballou, R. H. 2004. Business logistics/supply chain management: Planning, organizing and controlling the supply chain (5th edition). Upper Saddle River: Prentice Hall.

Department of Public Enterprises. 2010. Transnet freight rail. Available, http://www.dpe. gov.za/state-pg-9-29 (accessed 31 May 2010).

Dlamini, A. 2009. Revitalised transnet freight rail grabs growing share of container business. Business Day, 21 August 2009. Available, http://allafrica.com/stories/200908210263.html (accessed 22 May 2010).

FDM. Transnet Freight Demand Model 2009. Transnet Freight Demand Model Database. Unpublished project documentation. Stellenbosch University.

Harris, R. G. 1977. Economies of traffic density in the rail freight industry. The Bell Journal of Economics, 8(2): 556-64.

Havenga, J. H. 2007. The development and application of a freight transport flow model for South Africa. Unpublished doctoral thesis. Stellenbosch University.

Havenga, J. H. 2010. The role and development of the rail freight sector in South Africa. Unpublished project documentation. Stellenbosch University.

Havenga, J. H., Van Eeden, J. \& Simpson, Z. (FDM). 2009. Transnet freight demand model (FDM). Stellenbosch: unpublished internal project documentation.

Havenga, J. H., Van Eeden, J. \& Simpson, Z. (SOL). 2009. The state of logistics in South Africa - Sustainable improvements or continued exposure to risk? In the 6th Annual State of Logistics Survey for South Africa. Published by the CSIR, Stellenbosch University and Imperial Logistics.

Kwan, C. \& Knutsen, K. 2006. Intermodal revolution. China Business Review, 33(4): 20-25.

National Treasury. 2009a. Provincial budgets and expenditure review: 05/06-11/12. Available: http://www.treasury.gov.za/publications/igfr/2009/prov/default.aspx (accessed 22 September 2009).

National Treasury. 2009b. Estimates of public expenditure. 2009, Transport. Available: http://www.treasury.gov.za/documents/Estimates\%20of\%20Public\%20Expenditure/2009/ Vote\%2033.pdf (accessed 22 September 2009). 
Ndebele, S. 2009. Keynote address at the 5th Annual General Meeting of the Maputo Corridor Logistics Initiative, Port of Maputo and Open Day, 6 August 2009. Maputo, Mozambique. Available: http://www.mcli.co.za/mcli-web/mcli/agm/agm-2009/hon-sbusiso-ndebele.pdf (accessed on 21 May 2010).

Republic of South Africa. 2004. Accelerated and shared growth initiative for South Africa (AsgiSA). Available: http://www.info.gov.za/asgisa/asgisa.htm (accessed 22 May 2010).

Rodrigue, J. P., Comtois, C. \& Slack, B. 2009. The geography of transport systems (2nd edition). New York: Routledge.

Transnet. 2009. National infrastructure plan roadshow 2009, stakeholder engagement. June 2009.

United Nations. 2002. Commercial development of regional ports as logistics centres. New York: United Nations Publications.

Van Klink, A. A. \& van den Berg, G. C. 1998. Gateways and intermodalism. Journal of Transport Geography, 6 (1): 1-9.

Williams, B. M., Hoel, L. A. 1998. Freight planning requirements for interstate corridors. Transportation Quarterly, 52 (2): 39-48.

Wilson, R. 2008. 19th annual state of logistics report: Surviving the slump. Washington DC: Council for Supply Chain Management Professionals.

Table of acronyms and abbreviations

\begin{tabular}{|l|l|}
\hline AsgiSA & Accelerated and Shared Growth Initiative for South Africa \\
\hline ATD & average travel distance \\
\hline GFB & General Freight Business \\
\hline OD & Origin-destination \\
\hline
\end{tabular}

